may be allowed to point out that the fact mentioned by Prof. Virchow favours rather than disproves this view. If the plain between Hissarlik and the sea has been gradually formed by the detritus brought down by Scamander the materials would be of fresh.water origin. The observations made by Dr. Virchow appear therefore to me by no means to bear out the concinsions which it is said have been drawn from them.

15, Lombard Street, E.C., July I2

\section{JOHN LUBBOCK}

\section{On the Origin of Certain Granitoid Rocks}

DR. HICKs has very properly called attention to his prior discovery of the transitional nature of some hälleflintas, and I regret that $I$ overlooked this point in his valuable papers on the Pembrokeshire rocks. I may, however, be permitted to point out that my observations in Shropshire go further than those of Dr. Hicks, since the halleflinta observed in the Wrekin range passes not merely into "incipient gneiss, the metamorphic action being incomplete, a kind of semi-metamorphism and softening having taken place, etc." ; but into a true gneiss, distinctly foliated in bands of quarti, felspar, mica, and sometimes hornblende, and into granitoidite and granite. In the Wrekin we see the completion of the change of which Dr. Hicks recorded the earlier stages.

Wellington, Salop, July I2

\section{The Telephone}

EXPERIMENTS that I have recently made with a "Bell" telephone have convinced me that the sounds produced are the result of molecular change in the iron disk, and are the same in kind as those heard in the telephone of Reiss.

My experiments were made with a carbon transmitter and Bell receiver, using a small battery to generate the current. First I removed the bar magnet from the receiver, in accordance with a suggestion made by a writer in NATURE some months ago. The effect without the magnet was the same as with it. It then occurred to me that the intensity of the sound might be increased by using two disks instead of one. Accordingly I cut two circles out of a piece of sheet iron, leaving a narrow strip of the metal to connect them, of sufficient length to enable the disks to lie on either side of the reel, so as to form, in fact, an armature to the electro-magnet. On experimenting with this my anticipations were fully realised, the sound produced being more than double that from a single disk.

Now, while trying these experiments I held the disks loosely in my hand, without their being in any way fastened to the wood holding the reel, the effect being the same as if firmly secured. In fact, a common dinner knife or a rough piece of iron would emit sound if brought near enough to the core of the electromagnet.

I have since constructed a very efficient telephone receiver out of a block of wood two inches square and three-quarters of an inch thick. I then drilied a hole sufficiently large to receive the reel, and covered the block with thin sheet iron. It needs no ear-piece, and forms the most effective telephone receiver that I have seen. But, still turther to prove that the sounds produced are due to the magnetisation of the iron of the disk, and not to mechanical vibrations resulting from the electro-magnet, I made an iron reel, the flanges of which were two inches in diameter. Now, on covering this reel and placing it in circuit, the flanges of the reel gave: out sound as clearly as in the Bell telephone. In my jadgment this experiment renders it conclusive that the sounds proceed from the magnetisation and demagnetisation of the iron, and are therefore precisely the same in character as those formed by a Reiss receiver.

\section{St. John's Rectory, British Columbia}

\section{Inherited Memory in Birds}

SOME interesting communications have lately appeared in NATURE on this subject, accounting for the wonderful knowledge of routes and localities displayed by birds in their migrations, by the theory that the impressions made on the brains of the parents are transmitted to their offspring, and that which we call vaguely instinct is often inherited memory.

The following circumstance is hard to explain on any other theory :-

About twelve years ago I was residing on the coast of Co.
Antrim, at the time the telegraph wires were set up along that charming road which skirts the sea for twenty-five miles between Larne and Cashendall. During the winter months large flocks of starlings always migrated over from Scotland, arriving in the early morning. The first winter after the wires were stretched along the coast I frequently found numbers of starlings lying dead or wounded on the roadside, they having evidently in their flight in the dusky morn struck against the telegraph wires, not blown against them, as these accidents often occurred when there was but little wind. I found that the peasantry had come to the conclusion that these unusual deaths were due to the flash of the telegraph messages, killing any starlings that happened to be perched on the wires when working.

Strange to say, that throughout the following and succeeding winters hardly a death occurred among the starlings on their arrival. It would thus appear that the birds were deeply im. pressed and understood the cause of the fatal accidents among their fellow-travellers that previous year, and bence carefully avoided the telegraph wires; not only so, but the young birds must also have acquired this knowledge and perpetuated it, a knowledge which they could not have acquired by experience or even instinct, unless the instinct was really inherited memory derived from the parents whose brains were first impressed by it. Sudbury, Suffolk

J. SiNClair HOLDEN

\section{Butterfly Swarms}

SOME, at least, of the swarms of $V$.cardui originate in Africa, one of which I witnessed a day's march west of Sowakin, in Nubia, in March, 1869. Our caravan had started for the coast, leaving the mountains shrouded in heavy clouds, soon after daybreak. At the foot of the high country is a stretch of wiry grass, beyond which lies the rainless desert as far as the sea. From my camel I noticed that the whole mass of the grass seemed violently agitated, although there was no wind. On dismounting $I$ found that the motion was caused by the contortions of pupæ of $V$. cardui, which were so numerous that almost every blade of grass seemed to bear one. The effect of these wrigglings was most peculiar, as if each grass stem was shaken separately-as indeed was the case-instead of bending regularly before a breeze. I called the attention of the late J. K. Lord to the phenomenon, and we awaited the result. Presently the pupæ began to burst, and the red fluid that escaped sprinkled the ground like a rain of blood. Myriads of butterflies limp and helpless crawled about. Presently the sun shone forth, and the insects began to dry their wings; and about half-an-hour after the birth of the first, the whole swarm rose as a dense cloud and flew away eastwards towards the sea. I do not know how long the swarm was, but it was certainly more than a mile, and its breadth exceeded a quarter of a mile.

SYDNEY B. J. SKERTCHLY

\section{Distribution of the Black Rat}

From Prof. Giglioli's letter in Nature, vol. xx. p. 242, it appears that the black rat is more abundant and widely distributed in Italy than in England. I know of some half-dozen specimens having been caught from time to tixe in the city of London, and in November, 1876 , a male about six weeks old was caught, which lived in confinement for two years and three months. It was mated with a tame white one, and they had two litters of young which were black, save the feet, tip of tail, and a small brush of pure white upon the chest.

Grosvenor Road, Higbury New Park, July II

$$
\text { CHAS. COPPOCK }
$$

\section{Pine Pollen and Sulphur}

v $\mathrm{Bx}$ a coincidence which depends upon the season of pollen. discharge occurring at the same period in Scotland as in England, $I$ am enabled to send you an extract from the Haddingtonshire Courier of June 27 , which may serve to dissipate the "sulphureous theories" of Mr. Carpenter's opponents.

"The rustics in this district [Gifford] have been of late much interested in a peculiar shower which had fallen in the early morning of Monday last. All the pools on the roads were covered and fringed with a powdery substance strongly resembling the flowers of sulphur. A calculating Good Templar found that the fiery powder had been drifted more about the houses of those who loyed the flowing bowl than those who loved the 